\title{
Characteristics of individuals with hemiparesis according to perception about the difficulty climb stairs
}

\section{Características de indivíduos com hemiparesia segundo a percepção sobre a dificuldade na subida de escadas}

\author{
Fernando Wendelstein Cano', Daniela Parizotto', Stella Maris Michaelsen
}

\begin{abstract}
Introduction: climbing up and down stairs is entered directly into the Community ambulation and activities of daily living. In individuals with hemiparesis after stroke, this activity may be compromised due to deficits in components of body function and structures, activity and participation. Objective: To identify the characteristics of individuals with hemiparesis, according to the self-perception of difficulty climbing stairs and relate to components of body function and structures (BFS), activity and participation with the cadence of up / down stairs. Method: Twenty-five subjects ( $57.8 \pm 12.4$ years) with chronic hemiparesis ( $57.8 \pm 42.7$ months) were divided into two groups as perceived with and without difficulty climbing stairs by this particular question in the Stroke Specific Quality of Life Scale (SSQOL). In the BSF domain was rated lower limb motor impairment (Fugl-Meyer Scale), the activity domain, gait/mobility (gait speed, the Timed Up and Go-TUG) and balance (one-leg support and BERG) and participation domain the quality of life with SSQOL. Results: The group with self-perception without difficulty showed less motor impairment and higher levels of activity and participation. Strong correlations of the stair climbing cadence with the Fugl-Meyer Scale and TUG and between stair descent cadence with gait speed and TUG. Conclusion: Variables of body function andstructures, activity and participation are lower in the group with self-perceived difficulty in stair climbing and are correlated with the cadence of stair ascent and descent.
\end{abstract}

Keywords: self-perception, stairs ascend, hemiparesis.

\section{RESUMO}

Introdução: A atividade de subida e descida de escada está inserida diretamente na deambulação comunitária e em atividades de vida diária. Em indivíduos com hemiparesia após Acidente Vascular Encefálico (AVE), essa atividade pode estar comprometida devido a déficits nas variáveis de estrutura e função corporal, atividade e participação. Objetivo: identificar as características de indivíduos com hemiparesia, segundo a auto-percepção da dificuldade para subida de escadas e relacionar com variáveis de estrutura e função corporal (EFC), atividade e participação com a cadência de subida/descida de escadas. Método: Participaram 25 indivíduos ( $57,8 \pm 12,4 a n o s)$ com hemiparesia crônica $(57,8 \pm 42,7$ meses) divididos em dois grupos, segundo a percepção com e sem dificuldade para subir escadas, avaliada através desta questão específica, da Escala de Qualidade de Vida Especifica Para Acidente Vascular Encefálico (EVQE-AVE). No domínio de EFC foi avaliado comprometimento motor de membros inferiores (Escala de Fugl-Meyer), no domínio atividade, marcha/mobilidade (velocidade de marcha, Timed Up and Go-TUG) e equilíbrio (apoio unipodal, BERG) e no domínio participação a qualidade de vida pela EVQE-AVE. Resultados: O grupo com auto-percepção sem dificuldade apresentou menor comprometimento motor e maiores níveis de atividade e participação. Foram encontradas fortes correlações da cadência de subida de escadas com a Escala de Fugl-Meyer e TUG e da cadência de descida de escadas com velocidade de marcha e TUG. Conclusão: Variáveis de estrutura e função corporal, atividade e participação são inferiores no grupo com auto-percepção de dificuldade para subida de escadas e são correlacionadas com a cadencia de subida e descida de escada.

Palavras-chave: auto-percepção, escada, hemiparesia.

Corresponding author: Fernando Wendelstein Cano. Laboratório de Controle Motor - Centro de Ciências da Saúde (CEFID) - UDESC, Rua Pascoal Simone, 358 Coqueiros, Zip Code: 88080-350 - Florianópolis - SC, Email: fernandowcano@fernandocano.com.br

${ }^{1}$ Universidade do Estado de Santa Catarina (UDESC), Florianópolis (SC), Brazil.

Financial support: No financial support.

Submission date 13 July 2015; Acceptance date 16 October 2015; Online publication date 27 October 2015 


\section{INTRODUCTION}

Stroke is the major cause of neurological disability worldwide. ${ }^{(1)}$ According to Patel, et al. (2006), ${ }^{(2)} 34 \%$ of subjects regained their independence after three years of stroke and $26 \%$ remain with moderate or severe sequelae, affecting their activities of daily living for long periods or a lifetime. ${ }^{(3)}$

The stroke has a negative impact on functional performance, which can interfere with the social participation of these individuals and reduce their perception of quality of life. ${ }^{(4)}$ The new body condition and performance in carrying out simple activities, can influence the perception of difficulty in individuals to perform the tasks, ${ }^{(5)}$ such as climbing stairs. Many post-stroke individuals perceive their bodies as fragile, unknown and unreliable, features that can end up affecting your engine performance and away from the social activities, social life. ${ }^{(5)}$ A study shows that more than $30 \%$ of stroke survivors reported participation constraints to four years post-stroke. ${ }^{(6)}$

Even individuals who regained independent walking in the chronic phase, continue to show restraint in participation, ${ }^{(7)}$ and predicted that a small percentage of post-stroke individuals can walk functionally community. ${ }^{(8)}$ The ability for ascending and descending stairs is among the locomotor tasks committed to post-stroke individuals. ${ }^{(9)}$

Of subjects with hemiparesis who can walk up and down stairs, $20-30 \%$ still had problems after treatment, ${ }^{(7)}$ or using compensatory patterns to make walking. ${ }^{(10,11)}$

In recent years locomotion on stairs has been widely used as a method of evaluation, to be easy accessible and able to differentiate between healthy individuals of subjects with hemiparesis, ${ }^{(12)}$ besides being a good predictor of functional capacity, with moderate correlation with the degree of motor recovery. ${ }^{(9,13)}$

The upstairs and downstairs has also been used as an outcome measure in clinical studies. ${ }^{(12,14)}$ However, little is known about the structure variables and body function, activity and participation, which are domains of the International Classification Functionality (ICF), ${ }^{(15)}$ affect the ability to walk up and down stairs and how this affects participation. Thus, the study objectives were to identify the characteristics of individuals according to the perceived difficulty climbing stairs and relate to components of body function structures, activity and participation with the upstairs and down stairs cadence.

\section{METHOD}

The study is characterized as descriptive. Participants were individuals with chronic hemiparesis (> six months after a stroke), which roam staircase with or without the use of auxiliary equipment and sufficient cognitive level to understand the assessment tools (MiniMental $\geq 20$ points)(16) selected in the Programa de Atenção à Saúde a Portadores de Sequela de AVE and from the Clínica Escola do Centro de Ciências da Saúde e do Esporte da Universidade do Estado de Santa Catarina (CEFID/UDESC). Subjects were excluded if they had bilateral motor impairment, injury history and/or orthopedic surgeries that can affect the performance of the task of going up and down stairs, presence of other associated neurological disorders that interfere with the uphill task and down stairs and visual deficits uncorrected (lenses and / or glasses).

The groups were divided according to the perception, according to the last week in relation to the difficulty of climbing stairs, assessed through interviews using the issue related to the ladder of the Stroke Specific Quality of Life Scale (SSQOL), adding the words "without using the handrail": "You had difficulty climbing stairs without using a handrail? Where the possible answers are: (1) could not do at all, (2) too much trouble, (3) some difficulty, (4) a bit of trouble and (5) any difficulties even. Subjects with answers $\leq 4$ were allocated to group "with difficulties" and individuals with response equal to five in the group 'without difficulty'. The study was approved by Comitê de Ética em Pesquisas com Seres Humanos-CEPSH da UDESC no18137213.2.0000.0118.

The sample consisted of 25 individuals of both sexes, aged between 27 and 81 years and between 8 and 156 months post-stroke. Most individuals were male (76\%), predominantly affected the left side (72\%). Participants were divided into two groups (without difficulty and with difficulty), according to the perception of the difficulty climbing stairs. The group with difficulty made up $52 \%$ of the sample, the age of the participants ranged between 34 and 75 years and between 20 and 156 months of time after stroke. The age of the group without difficulty ranged from 27 to 81 years and between 19 and 156 months of time after stroke (Table 1).

To evaluate the upstairs and down stairs we used the stairs cadence test where subjects performed the ascending and descending on a stair with four steps $(15.4 \mathrm{~cm}$ high and $30 \mathrm{~cm}$ deep), at a comfortable speed and using the handrail as needed. The time was measured using a digital timer and calculated cadence in steps per minute. ${ }^{(11)}$

The variables, according to domains of ICF: body function and structures, activity and participation were assessed as follows: To Body Function and Structures was assessed motor impairment of the lower limb by this session of the Fugl-Meyer scale (LL-FMS), which presents inter-rater reliability (intraclass correlation coefficient (ICC) of 0.90$)^{(17)}$ scores are given on a scale of 0 to 2 points, being: (0) without function (2) full function. The total LL motor score graduates 0-34 points, and motor impairment level can be checked through the achieved score, being down 17 points a serious motor impairment; 18-22 points marked impairment; 23-28 moderate; and above 29 mild. ${ }^{(17,18)}$

For variable activity were evaluated functional mobility, through the Timed up and go test (TUG), which was timed how long the individual up from a chair with armrest $(45 \mathrm{~cm})$, walk a distance of 3 meters, turn 180 degrees, return to his 
Table 1. Characterization of the total sample and sub-groups as the perceived difficulty climbing stairs with no handrail use: self-perception with difficulty (w/difficulty) and self-perception without difficulty (wo/ difficulty) according to this Stroke Specificies Quality of Life Scale (EVQE-AVE).

\begin{tabular}{|c|c|c|c|}
\hline \multirow{2}{*}{ Characteristic } & $\begin{array}{c}\text { Total } \\
(n=25)\end{array}$ & $\begin{array}{l}\text { w/ difficulty } \\
(n=13)\end{array}$ & $\begin{array}{l}\text { wo/ difficulty } \\
\qquad(n=12)\end{array}$ \\
\hline & $M \pm S D$ & $M \pm S D$ & $M \pm S D$ \\
\hline Age (Years) & $57.81 \pm 12.40$ & $62.52 \pm 10.92$ & $54.62 \pm 13.13$ \\
\hline Time after stroke (months) & $57.82 \pm 42.70$ & $65.63 \pm 46.02$ & $49.44 \pm 39.10$ \\
\hline \multirow[t]{2}{*}{ Mini Mental (30) } & $25.20 \pm 3.10$ & $24.9 \pm 4.10$ & $25.40 \pm 1.80$ \\
\hline & $\mathbf{N}$ & $\mathbf{N}$ & $\mathbf{N}$ \\
\hline Gender (M/F) & $19 / 6$ & $9 / 4$ & $10 / 2$ \\
\hline Affected side (D/E) & $7 / 18$ & $5 / 8$ & $2 / 10$ \\
\hline Dominance (R/L) & $25 / 0$ & $13 / 0$ & $12 / 0$ \\
\hline
\end{tabular}

$\mathrm{M}(\mathrm{SD})=$ mean (standard deviation); $\mathrm{N}=$ number of subjects; $\mathrm{M}=$ male; $\mathrm{F}=$ Female; $\mathrm{R}=$ right; $\mathrm{L}=$ left

chair and sat leaning back against the backrest. ${ }^{(19)}$ Functional balance was assessed using Berg Balance scale, which consists of performing 14 tasks of ordinary activities in daily life with progressive difficulty. The tasks are scored 0-4 (0 = inability to perform the activity and $4=$ ability to perform the activity without difficulty). The maximum score is 56 points and a score below 36 points means a $100 \%$ risk of falls. The version used was translated and validated in Brazil, which has adequate interrater reliability (ICC 0.98). ${ }^{(20)}$ The static balance was evaluated by Unipodal Stance Test (UPST) to determine the maximum time that the individual remains in unipodal the paretic leg and leg not paretic in two conditions, closed and open eyes. The ICC $=0.99$ for both open eyes and closed eyes. Postures adopted as Springer et al protocol. (2007). ${ }^{(21)}$ The Walk Test of 10 meters assessed comfortable speed of gait (CG) and fast speed of gait (FG). ${ }^{(22-23)}$

To assess the participation was carried out Specifies the Quality of Life Scale for stroke - EQVE-AVE - translated version of SSQOL (Stroke Specific Quality of Life) which was adapted into Portuguese, and the internal consistency estimate or calibration stability of items and individuals was 0.92 . The scale consists of 49 items divided into 12 areas, with three responses opportunities developed in a Likert scale with scores from 1 to 5 . The benchmark for response refers to the week before the valuation date. The individuals in the sample were classified into three QOL levels: low (0-81), medium (82-163) and high (164-245). ${ }^{24}$

For statistical analysis, data were characterized by mean and standard deviation. To compare the characteristics of individuals and the self-perception of difficulty climbing a stair we used the t test for independent samples. To investigate the relationship between the components of body function and structures, activity and participation with the ascending and descending stairs we used the Pearson correlation coefficient. The classification was used for correlation: $r=0.10-0.30$, weak; $r=0.40-0.6$, moderate; $r=0.70-1$, strong. ${ }^{(25)}$ The tests were performed with SPSS software version 20.0, adopting a 0.05 significance level.

\section{RESULTS}

The group with the self-perception "without difficulty" of climb stairs presented a LL motor impairment and TUG lower that the group "with difficulty". The stair climbing cadence, fast walking speed, BERG scale and one unipodal stance time with open eyes on the paretic lower limb was higher in the group "without difficulty". Regarding participation, the group with self-perception "without difficulty" had a better quality of life than the group with self-perception "with difficulty" climbing stairs. (Table 2). No significant differences were found between the groups "with and without difficulty" at the activity of comfortable walking speed and unipodal stance with eyes open in the non-paretic leg and eyes closed in both lower limbs.

\section{Correlations}

The upstairs cadence showed strong correlations with motor impairment of the lower limb section of Fugl-Meyer scale and mobility at the TUG. The down stairs cadence showed strong correlations with mobility at TUG and the comfortable walking speed. The correlations are shown in Table 3.

\section{DISCUSSION}

This study suggests that both measures of perception difficulty climbing stairs and performance of motor function are important and complement the evaluation of a post-stroke individual. The clinical performance results were consistent with the perception reported by patients. Significant differences between groups with different perceptions, were found in almost all clinical trials, and the group that is perceived with difficulty in climbing stairs, presented performance results lower than the group without difficulty.

The use of perception for clinical evaluation has been studied by many researchers, ${ }^{(7,26-28)}$ and its application is still 
Table 2: Clinical data, mean (standard deviation) of all participants and subgroups as the perceived difficulty climbing stairs with no handrail use in hard (w/difficulty) without difficulty (wo/difficulty).

\begin{tabular}{|c|c|c|c|c|}
\hline Variable & $\mathrm{n}=\mathbf{2 5}$ & $\begin{array}{l}\text { w/ difficulty } \\
n=13\end{array}$ & $\begin{array}{c}\text { wo/ difficulty } \\
n=12\end{array}$ & $\mathbf{p}$ \\
\hline \multicolumn{5}{|l|}{ Structure and Body Function } \\
\hline Fugl-Meyer (points) & $27.45 \pm 6.14$ & $24.46 \pm 6.70$ & $29.58 \pm 3.89$ & 0.03 \\
\hline \multicolumn{5}{|l|}{ Activity } \\
\hline Stair climbing cadence (Steps/min) & $71.12 \pm 26.91$ & $57.96 \pm 28.16$ & $80.65 \pm 18.34$ & 0.03 \\
\hline Cadence down stairs (steps/min) & $88.62 \pm 37.01$ & $71.23 \pm 38.26$ & $99.18 \pm 26.89$ & 0.05 \\
\hline TUG (s) & $12.13 \pm 6.21$ & $14.36 \pm 7.19$ & $9.52 \pm 2.26$ & 0.04 \\
\hline Walking speed (comfortable) $(\mathrm{m} / \mathrm{s})$ & $0.93 \pm 0.27$ & $0.84 \pm 0.28$ & $1.02 \pm 0.20$ & 0.08 \\
\hline Walking speed (fast) (m/s) & $1.35 \pm 0.41$ & $1.17 \pm 0.38$ & $1.60 \pm 0.36$ & 0.01 \\
\hline BERG (points) & $51.70 \pm 5.31$ & $49.23 \pm 5.16$ & $54.75 \pm 1.29$ & 0.01 \\
\hline \multicolumn{5}{|l|}{ Unipodal (s) } \\
\hline $\mathrm{EO} / \mathrm{P}$ & $3.69 \pm 3.69$ & $2.21 \pm 2.62$ & $8.85 \pm 10.53$ & 0.04 \\
\hline $\mathrm{EO} / \mathrm{NP}$ & $10.80 \pm 9.64$ & $8.96 \pm 8.74$ & $16.91 \pm 12.59$ & 0.08 \\
\hline$E C / P$ & $1.28 \pm 1.42$ & $1.05 \pm 1.19$ & $1.68 \pm 1.65$ & 0.27 \\
\hline $\mathrm{EC} / \mathrm{NP}$ & $2.67 \pm 2.07$ & $2.79 \pm 2.30$ & $5.10 \pm 9.50$ & 0.39 \\
\hline \multicolumn{5}{|l|}{ Particiption } \\
\hline EQVE (points) & $196.01 \pm 33.03$ & $184.85 \pm 29.78$ & $210.09 \pm 25.97$ & 0.04 \\
\hline
\end{tabular}

Table 3. Correlations of variables of Body Function and Structures (BFS), Activity and Participation with the upstairs and downstairs cadence.

\begin{tabular}{|c|c|c|c|c|c|}
\hline \multirow{2}{*}{$\begin{array}{c}\text { Characteristic } \\
n=25\end{array}$} & \multirow{2}{*}{ Variables } & \multicolumn{2}{|c|}{ Upstairs cadence } & \multicolumn{2}{|c|}{ Downstairs cadence } \\
\hline & & Pearson $r$ & $\mathbf{P}$ & Pearson $r$ & p \\
\hline BFS & FMS & 0.75 & 0.000 & 0.68 & 0.000 \\
\hline \multirow[t]{9}{*}{ Activities } & TUG & -0.73 & 0.000 & -0.70 & 0.000 \\
\hline & BERG & 0.64 & 0.001 & 0.62 & 0.001 \\
\hline & Unipodal & & & & \\
\hline & $\mathrm{EO} / \mathrm{P}$ & - & - & - & - \\
\hline & $\mathrm{EO} / \mathrm{NP}$ & 0.42 & 0.04 & 0.43 & 0.03 \\
\hline & $\mathrm{EC} / \mathrm{P}$ & 0.55 & .004 & 0.51 & 0.01 \\
\hline & $\mathrm{EC} / \mathrm{NP}$ & - & - & - & - \\
\hline & Walking speed (comfortable) & 0.65 & 0.000 & 0.73 & 0.000 \\
\hline & Walking speed (fast) & 0.58 & 0.003 & 0.59 & 0.002 \\
\hline Participation & EQVE-AVE & 0.51 & 0.01 & 0.43 & 0.03 \\
\hline
\end{tabular}

FMS = Fugl-Meyer scale; TUG = Timed up and go test; BERG = Berg Balance Scale; EO/P = eyes open / paretic leg; EO/ NP = eyes open / not paretic leg; The EC/ P = eyes closed / paretic leg; EC / NP = eyes closed / leg not paretic; EQVE- AVE = Specifies Quality of Life Scale for stroke; steps / min = steps per minute; $\mathrm{m} / \mathrm{s}=\mathrm{meters} \mathrm{per} \mathrm{second.}$

under discussion for people with stroke, probably because common post-stroke deficits (eg aphasia, neglect, cognitive problems, depression) could compromise the results, with confusing answers on body function. ${ }^{(26,28)}$ Owens et al. (2002) ${ }^{(26)}$ found that there may be considerable differences between the analysis function by perception-based performance measurements, using categorical scale functional levels in female subjects in the acute phase of stroke. Suggest that the function measurements based on performance can be more accurate and appropriate in relation to perception. In this population, $\mathbf{7 4 . 3 \%}$ of the sample presented small divergence in the results of the great perception and performance, and largely overestimated their functional status. ${ }^{(27)}$ In a study by Stewart and Cramer (2013) ${ }^{(28)} 71 \%$ of patients who reported problems in upper limb function in clinical scales were classified as having little or no disability. Then suggesting that 
the inclusion of outcome measures reported by the patient may be important to a complete understanding of particularly motor deficits in patients with mild impairments. ${ }^{21}$ In the study by Silva and Gobbi (2005), ${ }^{(29)}$ the perception of a complex task, get off the bus stairs, was considered easy for $62.2 \%$ in the elderly, a fact that can be explained by the strategies adopted in this task because the trend is going down with foot side positioning step and united with the use of the handrail, having a perception of safety.

The perception results of this study indicate that for individuals with stroke inclusion perception measures, together with the clinical tests, may be important in clinical practice for post-stroke patients, providing more complete diagnostics also reported in the study by Stewart and Cramer (2013).(28) Among the measures the functional impairment of balance and displacement at a fast speed were the characteristics that most differentiate the two groups.

Individuals with self-perception "without difficulty" in climbing stairs have a higher score on the brazilian version of SSQOL, reflecting greater participation for individuals with self-perception "with difficulty climbing stairs." In addition, the SSQOL correlated significantly with the cadence on stairs. It was found in a systematic review of Faria et al. (2012)(22) among different assessments of quality of life (NHP, SSQOL, SF-36) to SSQOL) was the one that included the largest number of the ICF participation domain categories. Thus the relationship found in this study between SSQOL with the rise and down stairs can be indicative of the importance of this task in participation. However, studies with a larger number of individuals are required to confirm this result.

Compared to the average rate of stair climbing, our study found a value of $71.1 \pm 26.9 \mathrm{steps} / \mathrm{min}$, and the literature presents the following data of $71.1( \pm 10.30)$ steps $/ \mathrm{min}^{(30)}$ and $60.4 \pm 22.7 \mathrm{steps} / \mathrm{min}$. ${ }^{(10)}$ The average cadence down stairs, our study found the value of $88.6 \pm 37.0$ steps/ $\mathrm{min}$, mean that this was more than shown in literature $75.6 \pm 13.4$ and $58.8 \pm 23.7 .{ }^{(30)}$

Correlations between climbing up and down stairs found both measures of body function and structures as the activity and participation. Strong relationships found between stair climbing cadence with motor impairment in the lower limbs (FMS $/ r=0.75$ ) and mobility (TUG $/ r=-0.73$ ), were also found in studies of $\mathrm{Ng}$ et al. $(2013)^{(12)} r=0.80$ and $r=$ the FMS -0.73 in TUG; moderate correlations were also found in the two studies for BERG scale, which showed 0.68 in the study of $\mathrm{Ng}$ et al. (2013) ${ }^{(12)}$ and 0.64 in this study. Fransbjer et al. $(2005)^{(30)}$ found correlation with TUG $r=-0.86$. The study by Amaral-Natalio et al. (2011) ${ }^{(9)}$ found that the TUG and the FMS correlations with stair climbing were moderate ( $r=-0.61$ and 0.60 respectively). Much of the variables had strong correlations with the cadence down stairs, among the most significant are comfortable walking speed $(r=0.73)$ and the TUG $(r=-0.70)$, the study of Fransbjer et al. $(2005)^{(30)}$ stronger correlations were found (TUG $=-0.90$ and comfortable walking speed $=0.82$ ) while on study Amaral-Natalio et al. $(2011)^{(9)}$ moderate correlations with the TUG $(r=-0.64) .^{(10,13)}$

\section{CONCLUSION}

Before the two proposed objectives and results of this study, it is suggested that the evaluation of perception can be important in the evaluation of an individual with post-stroke hemiparesis, which may influence the performance of clinical trials, thus becoming an essential complement to clinical practice. Knowledge of the relationships found between the components of body function and structures, participation and activity with the ascent and descent of stairs also helps in guiding appropriate treatment.

\section{AUTHORS CONTRIBUTION}

FWC: Data collection and preparation of the article; DP: Data collection and preparation of the article; SMM: orientation and elaboration of the article

\section{COMPETING INTERESTS}

The authors declare no conflicts of interest.

\section{REFERENCES}

1. PAHO - Pan-American Health Organization. Regional Core Health Data Initiative. Available at: www.paho.org/english/dd/ais/coredata.htm. Acessado em 30 de junho de 2013.

2. Patel MD, Tilling K, Lawrence E, Rudd AG, Wolfe CD, McKevitt C. Relationships between long-term stroke disability, handicap and healthrelated quality of life. Age and Ageing. 2006;35(3):273-279.

3. Geurts $\mathrm{ACH}$, de Haart M, van Nes IJ, Duysens J. A review of standing balance recovery from stroke. Gait \& Posture. 2005;22(3):267-281.

4. Neto MG, Sales V, Portella DDA, Lacerda VB, Conceição CS, Dias RS. Qualidade de vida e desempenho funcional em pessoas com hemiparesia. Ter Man. 2013;11(52):223-227.

5. Kitzmüller G, Häggström T, Asplund K. Living an unfamiliar body: the significance of the long-term influence of bodily changes on the perception of self after stroke. Medicine Health Care and Philosophy. 2013;16(1):19-29.

6. Gadidi V, Katz-Leurer M, Carmeli E, Bornstein NM. Long-term outcome poststroke: predictors of activity limitation and participation restriction. Archives of Physical Medicine and Rehabilitation. 2011;92:1802-1808.

7. Carod-Artal FJ, González-Gutiérrez JL, Herrero JA, Horan T, De Seijas EV. Functional recovery and instrumental activities of daily living: follow-up 1-year after treatment in a stroke unit. Brain Injury. 2002;16(3):207-16.

8. Mudge S, Stott S. Timed walking tests correlate with daily step activity in persons with stroke. Archives of Physical Medicine and Rehabilitation. 2009;90:293-301.

9. Amaral-Natalio M, Nunes GS, Herber V, Michaelsen SM. Relação entre cadência da subida e descida de escada, recuperação motora e equilíbrio em indivíduos com hemiparesia. Acta Fisiátrica. 2011;18(3):146-150.

10. De Bujanda E, Nadeau S, Bourbonnais D, Dickstein R. Associations between lower limb impairments, locomotor capacities and kinematic variables in the frontal plane during walking in adults with chronic stroke. Journal of Rehabilitation Medicine. 2003;35(6):259-64.

11. Said CM, Goldie PA, Culham E, Sparrow WA, Patla AE, Morris ME. Control of lead and trail limbs during obstacle crossing following stroke. Physical Therapy. 2005;85(5):413-27.

12. Ng SS, Ng HH, Chan KM, Lai JC, To AK, Yeung CW. Reliability of the 12-step ascend and descend test and its correlation with motor function in people with chronic stroke. Journal of Rehabilitation Medicine. 2013;45(2):123-9. 
13. Oh-Park M, Wang C, Verghese J. Stair negotiation time in communitydwelling older adults: normative values and association with functional decline. Archives of Physical Medicine and Rehabilitation. 2011;92(12):2006-11.

14. Alzahrani M, Dean C, Ada L. Relationship between walking performance and types of community based activities in people with stroke: an observational study. Revista Brasileira de Fisioterapia. 2011;15(1):45-51.

15. World Health Organization (WHO). A Practical Manual for using the International Classification of Functioning, Disability and Health (ICF). 2013: Genebra.

16. Brucki SM, Nitrini R, Caramelli P, Bertolucci PH, Okamoto IH. Sugestões para o uso do Mini-Exame do Estado Mental no Brasil. Arquivos de Neuropsiquiatria. 2003;61(3B):777-81.

17. Fugl-Meyer AR, Jääskö L, Leyman I, Olsson S, Steglind S. The post stroke hemiplegic patient. I. A method for evaluation of physical performance. Scandinavian Journal of Rehabilitation Medicine. 1975;7(1):13-31.

18. Michaelsen SM, Rocha AS, Knabben RJ, Rodrigues LP, Fernandes CGC. Tradução, adaptação e confiabilidade Inter examinadores do manual de administração da escala Fugl-Meyer. Revista Brasileira de Fisioterapia. 2011;15(1):80-8

19. Faria CD, Teixeira-Salmela LF, Silva EB, Nadeau S. Expanded timed up and go test with subjects with stroke: Reliabity and comparison with matched healthy controls. Archives of Physical Medicine and Rehabilitation. 2011;93(6):1034-8.

20. Myamoto ST, Lombardi Junior I, Berg KO, Ramos LR, Natour J. Brazilian version of the Berg balance scale. Brazilian Journal of Medical and Biological Research. 2004;37(9):1411-21.

21. Springer BA, Marin R, Cyhan T, Roberts H, Gill NW. Normative Values for the Unipedal Stance Test with Eyes Open and Closed. Journal Geriatric Physical Therapy. 2007;30(1):8-15.
22. Faria CDCM, Silva SM, Corrêa JCF, Laurentino GEC, Teixeira-Salmela LF. Identificação das categorias de participação da CIF em instrumentos de qualidade de vida utilizados em indivíduos acometidos pelo acidente vascular encefálico. Revista Panamericana de Salud Pública. 2012;31(4):338-44.

23. Nascimento LR, Caetano LCG, Freitas DCMA, Morais TM, Polese JC, Teixeira-Salmela LF. Diferentes instruções durante teste de velocidade de marcha determinam aumento significativo na velocidade máxima de indivíduos com hemiparesia crônica. Revista Brasileira de Fisioterapia.2012;16(2):122-127.

24. Lima RCM, Teixeira-Salmela LF, Magalhães LC, Gomes-Neto M. Propriedades psicométricas da versão brasileira da escala de qualidade de vida específica para acidente vascular encefálico: aplicação do modelo Rasch. Revista Brasileira de Fisioterapia. 2008;12(2):149-156.

25. Dancey C, Reidy J. Estatística Sem Matemática para Psicologia: Usando SPSS para Windows. Porto Alegre, Artmed; 2006.

26. Owens PL, Bradley EH, Horwitz SM, Viscoli CM, Kernan WN, Brass LM, et al. Clinical Assessment of Function among Women with a Recent Cerebrovascular Event: A Self-Reported versus Performance-Based Measure. Annals Internal Medicine. 2002;136(11):802-11.

27. Polese JC, Nascimento LR, Faria CDCM, Laurentino GEC, Rodrigues-dePaula F, Ada L, et al. Percepção de hemiplégicos crônicos sobre o uso de dispositivos auxiliares na marcha. Revista Panamericana Salud Pública. 2011;30(3):204-208.

28. Stewart JC, Cramer SC. Patient-Reported Measures Provide Unique Insights Into Motor Function After Stroke. Stroke. 2013;44(4):1111-6.

29. Da-Silva MV, Gobbi LT. Percepção de dificuldade e comportamento locomotor de idosos ao descer degraus de ônibus. Motricidade. 2005;1(2):96-105.

30. Flansbjer UB, Holmbäck AM, Downham D, Patten C, Lexell J. Reliability of gait performance tests in men and women with hemiparesis after stroke. Journal of Rehabilitation Medicine. 2005;37(2):75-82. 